\title{
A Histochemical Study of Plant Nuclei in Rest and Mitosis
}

\author{
By
}

\section{Namio Shinke and Michio Shigenaga}

Botanical Institute, Kyoto Imp. Univ.

(With 9 Text-figures)

Received October 10, 1932



\section{Introduction}

While several biochemists such as Miescher, Kossel, LiLienfeld, MathewS and others ${ }^{1)}$ have convinced themselves of the presence of nuclein or nucleoproteins as the main chemical components of the nucleus, Hansteen-Cranner (1919), Grafe (1925), Grafe and Magistris (1926) and GuTSTEIN (1926) have laid stress on lipoids as the chief components of the nuclear substance. We have then the question of how these substances, either or both, are distributed among the morphological elements of the nucleus, that is, the chromosomes, the nuclear reticulum, the karyolymph, and the nucleoli.

For the purpose of solving this question, macrochemical methods of investigation are of little use, but histochemical methods are valuable, and accordingly SchWARZ (1892), ZaCHARIAS (1881, 1885 and 1898), HeINe (1895/96), NĚMEC (1909 and 1910), UNNA and FEIN (1921), and UNNA (1928) have adopted for this purpose the methods of staining and

1) Cited from KIESEL (1930). 
solution analysis, with which the chemical nature of the nuclear substances may be learned from their affinity to or solubility in certain definite dyes or chemical reagents. In the employment of these histochemical methods, however, we encounter certain difficulties. For example in the first method, we find a difficulty which is connected with the weak point, as pointed out by PratJe (1920), WiLson (1925) and some others, that this method is based merely on the assumption that the chemical affinity between the dyes and the nuclear substances plays the principal rôle in the staining. As a matter of fact, we have many cases in which it has been shown that this is true, but we have, on the other hand, a good many reasons to suppose that in other cases the staining is due to various other factors on the colloidchemical or physico-chemical side. In the second method, there are also some weak points owing to which a wrong conclusion is liable to be drawn, though this method may be more reliable than the former. The main difficulties which we encounter in this method are that the solubility of nuclear substances may, to a certain extent, become altered by different preliminary treatments of materials (NËMEC, 1910), and that there is a possibility of their being dissolved by the action of a certain enzyme in the cell instead of by the direct action of the reagents applied (OES, 1908). Furthermore, there is another difficulty in the accurate determination of the degree of solution of the nuclear elements. If the staining method is used combined with this solution method, the determination of the degree of solution becomes much easier, but, as pointed out by WERMEL (1927), it must be kept in mind that negative result obtained by staining may not necessarily mean solution of the substances in question. Neither of these methods alone is, therefore, trustworthy, though both have a noteworthy bearing upon the histochemical investigation, so far as they are used as supplementary tests to more precise methods.

The most reliable methods for the histochemical investigation must be those in which the colour reaction used for macrochemical tests is applied, though these reactions are often not available for this purpose. FEULGEN's nucleal-reaction for the detection of thymusnucleic acid and MILLON's reaction for that of proteins may be mentioned as such reactions. For the detection of lipoids we have as yet few methods which stand on a firm chemical basis, but staining methods which take advantage of the solubility of certain dyes, such as Sudan III, Scharlach red and some other dyes, in lipoids and fats, are used by many investigators with relatively few objections for the test of lipoids. 
In the present investigation, tests for thymusnucleic acid, lipoids and proteins were made on the plant nucleus as well as its constitutional morphological elements by the methods which are regarded as reliable and also by those of which the results are worthy of supplementing those obtained with the former. The description of each method used will be given in the appropriate place.

\section{Test for Nucleic Acid}

In his review of the colour reactions of thymusnucleic acid, DischE (1931) mentions three methods of detection : KILIANI's, FeULGEN's and DiscHE's. So far as the present authors' experience is concerned, the method of Dische is not applicable to histochemical purposes as the reagents destory the tissues, while the reaction of FEULGEN proves far more valuable for the purpose. In 1924, FEULGEN and RossENBECK reported a new method of detecting thymusnucleic acid in histological preparations of animal tissues, and called it the " nucleal-reaction" or "nucleal-staining." According to them, this method of test rests on a purely chemical basis and the mechanism of the colour reaction is more exactly defined by chemical terms than in the case of the ordinary staining reaction with basic dyes. The principle of this reaction rests on the fact that aldehyde-like substances which are derived from thymusnucleic acid through partial hydrolysis present a colour reaction with SCHIFF's reagent. While this reaction has been employed by many zoologists, only a few attempts have been reported by botanists. FUJII (1926), HeITZ (1931) and YAMAHA (1932) are those investigators, and they have obtained positive results in testing the chromosomes in some higher plants. In the present investigation, tests were made generally after FEULGEN's schedule (1926), fresh or preliminarily fixed material being used. The procedure adopted in the tests is as follows: Tissues are mildly hydrolysed with $1 \mathrm{~N} \mathrm{HCl}$ at $60^{\circ} \mathrm{C}$ for 3 to 5 minutes so as to set free the aldehyde-like group of the carbohydrate contained in thymusnucleic acid. They are washed in water for 5 to 10 minutes, and then treated with fuchsin-sulphurous acid (SCHIFF's reagent which is known as a detector of the aldehyde group) for 1 to 3 hours. When the reaction colour has completely developed, the tissues are thoroughly washed in water containing $\mathrm{SO}_{2}$, and then in distilled water, and dehydrated, cleared and mounted as usual.

If material contains thymusnucleic acid, it presents a reaction colour which is violet or reddish purple when seen through transmitted light under the microscope. 


\section{a) Pollen mother cells of Tradescantia reflexa}

i) Material fixed with acetic acid.)

Fresh pollen mother cells are smeared on a slide glass, and fixed with $30-35 \%$ acetic acid before testing.

With nuclei in the premeiotic phases and those in an early meiotic phase, sufficiently definite results are not obtainable, as in these stages the cells are apt to be off the slide glass. Observations are, therefore, inevitably limited to a later prophase and the following stages. In the late prophase, the nuclear spireme is found deeply coloured, while the karyolymph seems to have no tint, though the spireme, being complicatedly convoluted, makes critical observation difficult. In metaphase, the chromosomes are coloured, and often only their spiral portion or chromonemata stand out clearly, their ground substance or matrix being uncoloured (Figs. 1 and 2). A similar differentiation in colour is

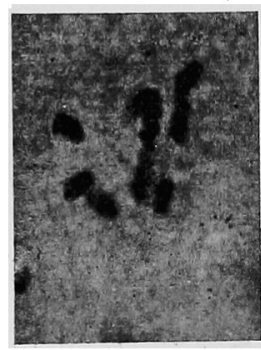

1

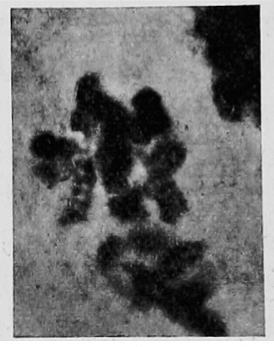

2

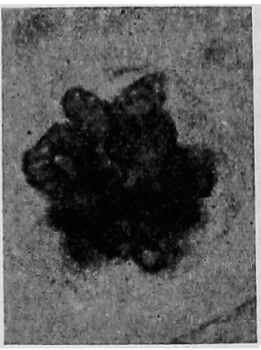

3

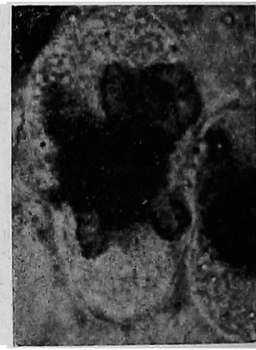

Figs. 1-4. Pollen mother cells of Tradescantıa reflexa in heterotype metaphase showing chromosome spirals coloured by FeULGeN's nucleal-staining. In Figs. 3 and 4 the chromosomes are swollen and the spirals are somewhat deformed in places.

also observed in telophasic chromosomes in which the matrix is faintly coloured and the spiral deeply. This differentiation in the chromosomes with regard to colour affords a certain amount of interest in relation to the problem of chromosome structure. Though we have not yet arrived at complete convergency of opinion on the minute structure of chromosomes, the spiral structure has of late years been increasingly recogniz. ed among cytologists. ${ }^{2}$ According to these authors, chromosomes in metaphase, anaphase and telophase consist of two portions, a hyaline or less chromatic matrix portion, and a highly chromatic spiral portion.

1) According to FEULGEN (1926), material to be used for the nucleal-reaction test should not be fixed with mixtures which contain formaldehyde or chromic acid (p. 1070).

2) KaUfmann (1926), FujiI (1926), KuWAda (1926 and 1927), SaKamura (1927), SharP (1929), MARTEN (1929), TAYLOR (1931) and others. 
It is not our present aim to discuss whether this spiral structure represents a natural structure or merely an artifact, but we wish here to emphasize the fact that these two portions can be distinguished from each other by their reaction.

When the fixation is not good enough, the chromosomes appear to be alveolar, mesh-like, or homogeneous and solid in structure (Figs. 3 and 4). In the case of the mesh-like or the alveolar appearance the non-coloured, hyaline substratum or matrix shows a marked contrast to the deeply coloured frame-work made up of alveolar walls.

In the interkinesis, the nuclear threads (chromonemata) which have uncoiled from the spiral and run sinuously in the nucleus are coloured, while the karyolymph appears to be colourless. Slender chromosomes in the homotype division show in most cases a mesh-like or an alveolar structure, and only in rare cases a distinct spiral. In the latter case the reaction colour is observed only in the spiral portion.

The spindle fibers, phragmoplast, and cytoplasm are all colourless in both the heterotype and the homotype division.

ii) Materials fixed with the mixture of acetic acid and corrosive sublimate ${ }^{1)}$.

Microtome sections. As in this case the material has been passed through graded alcohols before being imbedded in paraffin, the violet colour reaction, if it takes place, is due to the presence of thymusnucleic acid, and not of plasmologen (FEULGEN, 1926 p. 1064). The results obtained from this material are generally similar to those described above. The distinct spirals which present the positive colour reaction are also not infrequently found in the chromosomes, but this spiral structure is of less frequent occurrence than the alveolar.

b) Pollen mother cells of Lilium tigrinum fixed with absolute alcohol

Microtome sections. In the synizesis stage both karyolymph and nucleoli are very clearly seen to be negative in reaction. The chromosomes show, on the other hand, the positive reaction very distinctly.

c) Pollen mother cells of Oenothera sp. fixed with the mixture of acetic acid and corrosive sublimate

Microtome sections. In this plant, the chromosomes in the heterotype division show only a very weak reaction and are very lightly col-

1) This mixture is the one recommended by FEULGEN (1926) as the best fixative for the purpose of the nucleal-reaction (p. 1070). 
oured as is the case also with the somatic chromosomes of Marsilia to be described below, while nuclei in the connective tissue of the anther and those in the tapetal cells present a more distinct reaction.

d) Somatic cells of Tradescantia reflexa fixed with the mixture of acetic acid and corrosive sublimate

Microtome sections. In the connective tissue of the anther and in the tapetal cells resting nuclei were examined with special attention to the reaction of the karyolymph.

As in the case of the smear and the fixed preparations of pollen mother cells, mentioned above, the karyolymph sometimes appears at first sight as if it were coloured, but closer observation with special attention to the optical illusion due to the reaction colour of the reticulum, seems to disclose that this is actually not the case.

\section{e) Root tip cells of Vicia Faba}

i) Fresh materials.

Root tips of Vicia Faba in toto are hydrolysed with $1 \mathrm{~N} \mathrm{HCl}$ at $60^{\circ}$ $\mathrm{C}$, and then the texture of the tissues is loosened by a slight pressure on the cover glass.

In the resting stage, the nuclear reticulum and its thickened nodes are positive in reaction, while the nucleolus is negative. The nuclear threads in the prophase are distinctly positive. In metaphase, the chromosomes, which generally present an alveolar or a glassy homogeneous solid appearance, are also positive, and in relatively rare cases they show. the spiral structure, which is positive as well. In the early telophase, the chromosomes making a decided "tassement polaire" are also positive to the reaction. In a stage transitional to interkinesis, the axial row of alveoli in the chromosome which has been noticed by many cytologists is recognizable. These alveoli do not present any colour reaction. In his paper dealing with the origin of nucleoli, HeiTz (1931) mentions without going details, that FEULGEN's nucleal-reaction is positive with chromosomes in root tip cells of Vicia Faba. From his coloured figure, Fig. 14 in which anaphasic and telophasic division figures are reproduced, it is seen that the alveole walls or zigzag part of the chromosomes is positive to the reaction.

OES (1908) express the view that in nuclei in the resting stage nucleic acid is less in amount than in those in dividing stages. This view is so far in accord with the results we obtained that the reaction colour is lighter in the resting nuclei than in the chromosomes, and that 
it is deeper in the nuclei in the dividing zone of the root tips than in the stretching zone.

ii) Materials fixed with the mixture of acetic acid and corrosive sublimate.

Microtome sections. The results obtained from this material are in general the same as those obtained from fresh material. The reaction of the karyolymph appears to be negative in this material too. The cell wall, nucleoli, cytoplasm and spindle fibers are also negative to the reaction.

f) Root tip cells of Zea Mais fixed with the mixture of acetic acid and corrosive sublimate

Microtome sections. In root tip cells of this plant, the nucleolus can frequently be found in the metaphase. Counter-staining with indigo-carmine brings it out blue, while the chromosomes are red or violet, presenting the reaction colour (Fig. 5). In this plant the chromosomes are small in size and consequently no spiral structure is recognizable, as is generally the case with such small chromosomes.

g) Root tip cells of Marsilia quadrifolia fixed with the mixture of acetic acid and corrosive sublimate

Microtome sections. In this plant the reaction of the nuclei and chromosomes is very weak even when prolonged hydrolysis and longer immersion in SCHIFF's reagent are applied.

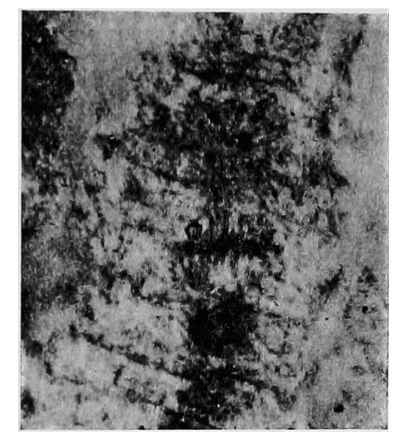

Fig. 5. Section of root tip of Zea Mais, showing chromosomes in metaphase coloured by nucleal-staining and nucleolus and spindle fibers not coloured.

\section{h) Fresh material of Spirogyra sp.}

In the Spirogyra sp. used in this test, the nuclei and nucleoli showed no nucleal-reaction at all. This is the only exceptional case we have met with. Hydrolysis being allowed to take place for various lengths of time, 2,4 , and 10 minutes at various temperatures, $40^{\circ} \mathrm{C}$, $60^{\circ} \mathrm{C}$, and $80^{\circ} \mathrm{C}$, no case was found where they were positive in reaction. The result was also negative when the tests were made with material fixed with the mixture of acetic acid and corrosive sublimate.

The negative result of the Spirogyra nuclei reminds us of the 
report of TRÖNDLE (1912) in which it is emphasized that in this alga the chromatic substance is lodged in the nucleolus. The results we obtained show, however, that the nucleolus is also negative in reaction.

From the results of the tests mentioned above, it may be concluded that, at least in pollen mother cells of Tradescantia reflexa and Lilium tigrinum, and in the root tip cells of Vicia Faba, thymusnucleic acid is contained in the nuclear reticulum as well as in the chromosomes, while it is lacking in the cytoplasm, the karyolymph, the spindle fibers and the nucleoli. The tests of chromosomes in Tradescantia and Vicia show, moreover, that their morphological components, the spiral and the matrix, differ from each other in reaction. In the former the thymusnucleic acid reaction is positive, while in the latter it is hardly so. Certain exceptional cases are exemplified by Oenothera sp., (pollen mother cells) and Marsilia quadrifolia (root tip cells) where the nuclealreaction of chromosomes or nuclei is very weak, and by Spirogyra sp. where it is quite negative.

\section{Test for Lipoid Substances}

The definition of the term lipoid is rather vague; some authors use it as including fats, while others talk about fats and lipoids. We employ this term here in the sense of not including the true fats.

In his histochemical tests for lipoids KaWAMURA (1911) has referred to the following properties : optical properties, physical and chemical properties (solubility, myeline-formation), staining property, and properties which can be distinguished from one another by the use of various fixing methods, such as SMITH's, FIsCHER's, GoLODEz's and CiACCIO's. In his recent review of various histochemical methods of lipoid detection, Schmidtmann (1928) refers also to these properties and classifies the methods as follows (p. 999).

a) Physical methods (regarding the optical property and solubility).

b) Chemical methods.

c) Special staining methods (with Sudan III, Scharlach red, Nile blue sulphate).

The results we obtained with these different methods of investigation point to a harmonious conclusion on the whole.

\section{a) With Physical Method-Solubility}

As it seems convenient to describe the results obtained with this method of test together with those obtained for nucleoprotein, the description will be given in Chapter IV together with the latter. 


\section{b) With Chemical Method}

Schmidtmann (1928) cites ChristelleR's method as a chemical method for the general test of lipoid substances. This method has been employed by CZAPEK (1919) in his histochemical studies in plants and is appreciated by him as an effectual method. In this method, the materials, either fresh or fixed (with formalin), must be kept in a water solution of phenylhydrazin hydrochloride at $37^{\circ} \mathrm{C}$ for 24 hours. According to our experience, there is in this method a certain disadvantage which is connected with the fact that the reagent itself, if it is kept for 24 hours, even without any material in it, may often produce a red tint like the reaction colour in the test tube on being mixed with potassium ferricyanide solution and $\mathrm{HCl}$ as directed by the method. In this respect, therefore, special attention has to be paid in employing this method.

With CHRISTELLER's method, the nuclei in root tip cells of Vicia Faba swell, but show the red reaction colour. The nucleolus generally seems uncoloured, while the cytoplasm shows a distinct reaction colour. The chromosomes in metaphase and anaphase generally swell and are coloured red. It must be noted here, however, that the colour reaction does not always take place in the chromosomes, and that when it takes place, the intensity of the colour varies to a considerable extent.

The nucleus in Spirogyra generally gives no reaction colour at all, as stated by CzAPEK (1919).

\section{c) With Staining Method}

The dyes used in this method are: Sudan III, Scharlach red, Nile blue sulphate, chlorophyll, and WEIGERT's haematoxylin, especially the first named dye, Sudan III, with or without counter-staining with HEIDENHAIN's haematoxylin. When the counter staining is employed, minute structures in the cell become distinct, and it makes examination easier.

The materials to be stained are fixed according to Craccio's scheme for lipoid fixation, the various successive parts of the procedure being as follows: (1) fixation with CiACCIo's fixative containing potassium bichromate, formalin and acetic acid; (2) post-chroming in a $5 \%$ potassium bichromate solution for about a week; (3) thorough washing in water ; (4) a very rapid dehydration with graded alcohols and imbedding in paraffin. Sections are stained, and mounted with a glycerin-gelatine mixture. 
According to CrACCIO ${ }^{1)}$, the fixation with potassium bichromate makes some lipoid substances such as kephaline, kephaline mixutre, fatty acids and soap insoluble in the ordinary fat solvents, while neutral fats, cholesterin, glycerinester, sphingomyeline, cerebroside, and cholesterin-fatty-acid mixture retain their solubility in these solvents.

i) Pollen mother cells of Tradescantia reflexa.

In preparations stained with Sudan III ${ }^{2)}$, the cytoplasm, the nuclear reticulum, the spiremes, the chromosomes and the nucleoli are stained orange red more or less strongly. The following descriptions are based on observations of preparations counter-stained with HeIDENHARs's haematoxylin.

In a late prophase, the chromosomes mainly take Sudan III, and a small amount of haematoxylin, while the karyolymph appears not to retain either of the dyes. In metaphase and anaphase the chromosomes stain as in the late prophase, but are now noticeably light-refracting. The outer or peripheral region of the chromosomes takes haematoxylin more than the core, which is stained light orange. In the telophase, when the chromosomes are closely clumped together, they show only a light tint of Sudan III, and this tendency becomes more evident in interkinesis. In this stage, the slender nuclear threads which run sinuously in the daughter nuclei are found stained mostly with haematoxylin. The cytoplasm, on the contrary, does not show any change in stainability during division, but is found deeply stained orange or reddish orange throughout the stages, the colouring being especially deep in the region of the phragmoplast. Spindle fibers seem to take Sudan III, though this can not be decidedly stated. It must be mentioned here that the periplasmodial nuclei and those in the wall layers of the anther take haematoxylin more than Sudan III, as in those of pollen mother cells in interkinesis. This makes a marked contrast to the case of the chromosomes in metaphase and anaphase where they are light orange, taking more Sudan III than those nuclei do.

ii) Root tip cells of Vicia Faba.

In the single staining with Sudan III, the chromosomes, the reticulum, the nucleoli, and the cytoplasm are red as in the case of pollen mother cells of Tradescantia reflexa. When counter-staining with haematoxylin is employed, the chromosomes in metaphase and anaphase take, both dyes though only lightly, and are dark orange in colour, without showing, in this case of root tip cells, much difference from the

1) Cited from Kawamura (1911) and Schmidtmann (1928, p. 1007).

2) Used in an alcohol-aceton solution after ARNDT (1924). 
result obtained in the reticulum or fine nuclear threads in the resting or early prophasic nuclei, while the cytoplasm and nucleoli take more Sudan III than the chromosomes, and are reddish orange. The karyolymph and spindle fibers are less light-refracting and remain unstained in both the single and the double stainings.

While the results obtained with the other lipoid-staining dyes, Scharlach red, chlorophyll, and Nile blue sulphate are, generally speaking, the same as those obtained with Sudan III in the chromosomes as well as the other elements in the cell in different stages of mitosis, special mention is needed for those obtained with KULTSCHITZKY's modification ${ }^{1)}$ of WEIGERT'S haematoxylin method. In pollen mother cells of Tradescantia reflexa fixed with Ciaccio's method, a linear row of droplets of obscure nature is often found in the heterotype metaphasic and anaphasic chromosome along its longitudinal axis (Fig. 6). With WeIGERT's haematoxylin, the chromosomes are diffusely stained and light greyish blue, except these droplets, which are deeply stained. The spindle fibers and the nucleoli are deeply stained with this haematoxylin, while the cytoplasm, which is deeply stained by

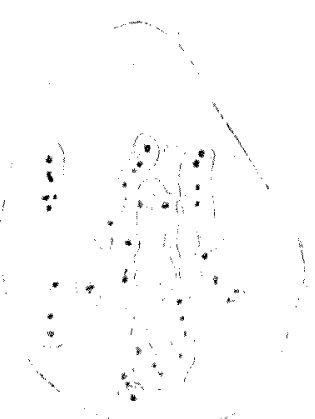

Fig. 6. Camera drawing of a pollen mother cell of Tradescantia reflexa showing chromosomes in heterotype metaphase stained with WEIGERT'S method. the other methods of lipoid staining, is stained only rather faintly.

From the results mentioned above, it is seen that the lipoid staining reaction is more or less distinctly positive in the nuclear reticulum, the chromosome, the nucleolus, the cytoplasm and the phragmoplast, while it is hardly so in the karyolymph. It also seems highly probable that the spindle fibers contain a certain lipoid substance.

\section{Test for Proteins}

of the various colour reactions for the detection of proteins, only some are available for histochemical purposes. The reactions used in the present investigation are MiLlon's, the xanthoproteic, and the biuret reaction, which are commonly used in histochemical studies with relatively few objections ${ }^{2}$.

1) See Romeis (1928) p. 458.

2) MEYER (1920, p. 63) has pointed out that some aromatic substances also present the colour reaction with MILLON's reagent. 


\section{a) Biuret Reaction}

i) Fresh pollen mother cells of Pinus Thumbergii,

Fresh pollen mother cells are smeared on a slide glass, and tested. As soon as a concentrated $\mathrm{NaOH}$ solution is added to the material, the pollen mother cells are coloured violet. Closer observation shows that here the cytoplasm is diffusely violet, and the nucleus which swells enormously, taking on the appearance of a homogeneous globe, shows only a tinge of violet. The nuclear elements, both reticulum and nucleolus, swell under the influence of the reagent, and are not discriminable.

ii) Root tip cells of Vicia Faba fixed with a mixture of acetic acid and corrosive sublimate.

The results are quite the same as those obtained with the fresh pollen mother cells just described above.

iii) Fresh material of Spirogyra sp.

Although an extraordinary contraction of the chlorophyll band prevents accurate observation of the nucleus nothing coloured violet is found in the cell.

\section{b) Xanthoproteic Reaction}

As this reagent destroys the inner structure of the cell to a considerable extent, close observation is hardly possible.

i) Fresh pollen mother cells of Pinus Thumbergii.

Pollen mother cells present on the whole a faint yellow colour, but neither chromosomes nor nucleoli are observable.

ii) Root tip cells of Vicia Faba fixed with a mixture of acetic acid and corrosive sublimate.

The root tip cells show a strong positive reaction, presenting the yellow reaction colour, but accurate observation of the minute cell structures is scarcely possible. The nucleus appears to be yellow, but seems somewhat faint in colour as compared with the colouring of the cytoplasm.

iii) Fresh material of Spirogyra sp.

The nucleus of Spirogyra is coloured faintly yellow.

c) MILlon's Reaction

i) Pollen mother cells of Tradescantia reflexa.

Tests are made by crushing fresh anthers on a slide glass with a drop of the reagent, which is previously warmed. 
In the prophasic nucleus, the nuclear threads, which are slightly light-refracting are coloured yellowish orange, and the karyolymph faintly red. The red tint of the karyolymph is generally so light that we may miss the colouration unless special attention is paid to it, although it is pretty deep in the peripheral region near the nuclear membrane. Chromosomes in metaphase as well as anaphase are lightrefracting and coloured orange, when they appear to be of a solid structure. When, however, as is generally the case in this test, an axial row of vacuoles is found in the chromosome, so that it may present a scalariform appearance, it is not easy to determine how these vacuoles are coloured, although in the marginal portion of the chromosome it is clear that it is light-refracting and coloured yellowish orange. The ground substance of the spindle is coloured light orange except the area near the chromosomes where it is faintly red, while the spindle fibers present the typical brick colour as reported by HeINE (1895/96).

The reaction of the clumped together telophasic chromosomes is the same as that of the nuclear threads in prophase, and that of the phragmoplast is typical in colour as in the spindle fibers. The reaction of the cytoplasm is also positive and typical throughout the stages investigated.

ii) Pollen mother cells of Pinus Thumbergii.

The nuclear threads in prophase are coloured yellowish orange, as in the case of Tradescantia reflexa. In one instance it was noticed that in a synizetic nucleus the karyolymph appeared as if it was coloured. though very faintly.

ii) Pollen mother cells of Lilium tigrinum fixed with the mixture of acetic acid and corrosive sublimate.

The reticulum in the resting stage and the synizetic ball in the synizetic stage present the typical brick colour, while the karyolymph remains uncoloured in these stages. The chromosomes in metaphase as well as in anaphase are coloured also. The nucleolus, which is lightrefracting, generally shows no positive reaction. The cytoplasm also presents the typical brick colour reaction.

iv) Fresh root tip cells in Vicia Faba.

Longitudinal hand sections of root tips are immediately tested with the reagent. The nuclear reticulum, prophasic nuclear threads and metaphasic chromosomes are light-refracting and coloured lightly red. The colouration of the nucleolus is indefinite. It is coloured faintly red, in some cases, and quite colourless in others. These results are in accord with MEYER's statement that the reaction is weaker in the 
nucleolus than in the chromatin (MEYER, 1920, p. 221). The cytoplasm gives the typical positive reaction colour in this material too.

v) Fresh material of Spirogyra sp.

The nucleus presents a very intense typical positive reaction, showing that it abounds in proteins.

From the results we obtained it is seen that the xanthoproteic and biuret reactions are not available for the purpose of the present investigation, because the morphological elements of the nucleus with which the tests are to be made are destroyed or made to swell to such an extent that nothing is discernible in the nucleus. With Millon's reagent the typical brick colour is presented by the spindle fibers, phragmoplast and the cytoplasm. In the nuclear reticulum and the chromosomes the reaction colour is not always typical but orange or yellowish orange, and in the karyolymph it is very faint, and sometimes not perceptible. In the nucleolus the reaction is negative in general. From these results it seems that the nuclear reticulum and the chromosomes contain a certain amount of proteins in the free or a combined form, and the nucleolus hardly any or a small amount of proteins in some form or other.

\section{Supplementary Tests}

\section{1) Test with the solution analysis method}

If nucleic acid or nucleoproteins and lipoid substances are com. ponents of the nuclear and the chromosome substance, the nucleus and the chromosomes should be dissolved by those chemical reagents which can dissolve these substances. From this point of view, solution analysis tests were made with root-tips of Vicia Faba as supplementary to the tests mentioned above, FEULGEN's nucleal-staining, Craccio's lipoid staining, and staining with HEIDENHAIN's iron haematoxylin being employed after treatment with the dissolving reagent to make the determination of the degree of solution of the substances in question easy. The method of procedure is as follows :- Root tips are immersed in various chemical reagents most of which are known to be nuclear and chromosome solvents, the concentrations of the water solutions of . the reagents used being as presented in the paper of YAMAHA (1927) in which the results of his study of the influence of a considerable number of reagents upon the cell elements were reported. The material is immersed in the chemicals for 4 hours in one series and for 24 hours in another, generally at $23^{\circ} \mathrm{C}$, with or without previous fixation with $30 \%$ 
acetic acid for one minute. Both series of materials, fixed and fresh, are then tested by FEULGEN's nucleal-reaction method and CIAccio's lipoid staining method.

The microscopical observation shows that in the fixed material the nuclei and chromosomes are scarcely dissolved by the reagents in the times mentioned, while in the fresh material the effect upon the nuclear elements is diverse. The results obtained from fresh material treated with lipoid solvents are tabulated in Table I. Since the degree of solution is different in different tissues, only those results are given in this table as well as the following ones, which were obtained in a few deep, inner layers of periblem close to the plerome where the nuclear elements are most strongly resistant to the action of the reagents (cf. ShIGENAGA, 1933).

In the following tables the following marks and abbreviations are used :

- : no solution

+ : solution to a certain extent

++ : complete solution

0 : negative reaction

$x$ : positive reaction

* : remarkable diversity in the results according to kinds of tissue

$(+)$ : dissolved

$(-)$ : not dissolved

drop : droplets presenting the reaction colour in the cytoplasm

$\mathrm{Ct}$ : chromatin

Cs: chromosome

$\mathrm{Kt}$ : karyotin

$\mathrm{h}$ : hour

Rt: root tip

fr : fresh

From Table 1, we see that chromosomes and resting nuclei in fresh material are dissolved by most of the so-called lipoid solvents except methyl- and ethyl-alcohols in which many lipoids such as kephaline, cuorin, etc. are not soluble (see BANG, 1911, p. 225). The nucleal-staining shows that thymusnucleic acid which is dislocalized and kecomes diffusely distributed within the boundary of the nucleus or the territory of the chromosomes, is gradually spread over the surrounding cy toplasm where it often takes the form of droplets presenting the colour of the nucleal-reaction.

The results obtained from nucleoprotein dissolving tests made with fresh material are given in Table 2. 
Table 1, a

(Materials immersed for 4 hours).

\begin{tabular}{|c|c|c|c|c|c|c|}
\hline & \multirow{2}{*}{$\begin{array}{c}\text { Chro- } \\
\text { mosome }\end{array}$} & \multirow{2}{*}{$\begin{array}{c}\text { Nuclear } \\
\text { reticu- } \\
\text { lum }\end{array}$} & \multicolumn{2}{|c|}{ Cytoplasm } & \multirow{2}{*}{$\begin{array}{c}\text { Nu- } \\
\text { cleolus }\end{array}$} & \multirow{2}{*}{ Results of Yамана (1927) } \\
\hline & & & N.R. & \begin{tabular}{|l} 
Sudan \\
III.
\end{tabular} & & \\
\hline Benzene & + & + or - & $x$ & $x$ & 一 & $\begin{array}{l}\mathrm{Kt}(-) ; 1 \mathrm{~h} ; \text { con.(?); Vicia } \\
F a b a ; \mathrm{Rt} ; \text { fr. }\end{array}$ \\
\hline $\begin{array}{l}\text { Benzene } \\
\text { water }\end{array}$ & + & & $x$ & & & \\
\hline Aceton water & + & + or - & 0 & drop $\times$ & - & $\begin{array}{l}\text { Cs }(-) ; 1 \mathrm{~h} ; 100 \times 2-1 \% \\
\text { Vicia Faba; Rt;fr. }\end{array}$ \\
\hline Aniline & ++ & + or - & drop $x$ & drop $x$ & - & \\
\hline Aniline water & + & & $x$ or 0 & & & $\begin{array}{l}\text { Cs }(+) ; 1 \mathrm{~h} ; 3 \% ; \text { Vicia } \\
\text { Faba;Rt;fr. }\end{array}$ \\
\hline Amylalcohol & ++ & & drop $x$ & drop $x$ & - & \\
\hline $\begin{array}{l}\text { Amylalcohol } \\
\text { water }\end{array}$ & ++ & & $x$ & & & $\begin{array}{l}\mathrm{Cs}(-) ; 1 \mathrm{~h} ; 4 \% ; \text { Vicia } \\
\text { Faba; Rt; fr. }\end{array}$ \\
\hline Ether & + & + or - & $x$ & $x$ & - & \\
\hline Ether water & ++ & & $x$ & & & $\begin{array}{l}\text { Cs }(+) ; 1 \mathrm{~h} ; 10 \% ; \text { Vicia } \\
\text { Faba; Rt; fr. }\end{array}$ \\
\hline Xylene & + & & $x$ & & & \\
\hline Xylene water & ++ & + or - & $x$ & drop $x$ & + or - & $\begin{array}{l}\text { Kt }(+?) ; 1 \mathrm{~h} ; \text { con. }(?) \\
\text { Vicia Faba; Rt;fr. }\end{array}$ \\
\hline Chloroform & + or - & + or - & 0 & $x$ & - & \\
\hline $\begin{array}{l}\text { Chloroform } \\
\text { water }\end{array}$ & ++ & & $x$ & & & $\begin{array}{l}\mathrm{Kt}, \mathrm{Cs} ;(+) ; 1 \mathrm{~h} ; \text { con. ca. } \\
0.7 \% ; \text { Vicia Faba; Rt; fr. }\end{array}$ \\
\hline $\begin{array}{l}\text { Na-glyco- } \\
\text { cholate, } 2 \%\end{array}$ & $-*$ & - * & 0 & $x$ & - & \\
\hline $\begin{array}{l}\text { Ethylalcohol, } \\
50 \%\end{array}$ & - & & 0 & & & $\begin{array}{l}\text { Kt, Cs }(-) ; 1 \text { h ; con. var.; } \\
\text { Vicia Faba; Rt; fr. }\end{array}$ \\
\hline $\begin{array}{l}\text { Methylalco- } \\
\text { hol, } 50 \%\end{array}$ & - & - & 0 & $x$ & - & $\begin{array}{l}\text { Kt, Cs }(-) ; 1 \text { h ; con. var.; } \\
\text { Vicia Faba; Rt; fr. }\end{array}$ \\
\hline Phenol, 1/10 M. & + & + or - & $x$ & $x$ & - & $\begin{array}{l}\mathrm{Kt}, \mathrm{Cs}(+) ; 1 \mathrm{~h} ; \mathrm{M} \times 2^{-3} \\
\text { Vicia Faba; Rt; fr. }\end{array}$ \\
\hline
\end{tabular}


Table 1, b

(Materials immersed for 24 hours).

\begin{tabular}{|c|c|c|c|c|c|}
\hline & \multirow{2}{*}{$\begin{array}{l}\text { Chromo- } \\
\text { some }\end{array}$} & \multirow{2}{*}{$\begin{array}{l}\text { Nuclear } \\
\text { reticulum }\end{array}$} & \multicolumn{2}{|c|}{ Cytoplasm } & \multirow{2}{*}{ Nucleolus } \\
\hline & & & N.R. & Sudan III. & \\
\hline Benzene & + & & $x$ & & \\
\hline Benzene water & ++ & tor - & drop $x$ & $x$ & - \\
\hline Aceton water & + & + or - & $x$ & drop $x$ & + or - \\
\hline Aniline & ++ & + or - & drop $x$ & drop $x$ & - \\
\hline Aniline water & ++ & & $x$ & & \\
\hline Amylalcohol & $+t$ & + or - & $x$ & drop $x$ & - \\
\hline Amylalcohol water & ++ & & $x$ & & \\
\hline Ether & + & & $x$ & & \\
\hline Ether water & ++ & + or - & $\times$ & $x$ & - \\
\hline Xylene & + & & $x$ & & \\
\hline Xylene water & ++ & + or - & $x$ & drop $x$ & + or - \\
\hline Chloroform & + & & 0 & & \\
\hline Chloroform water & ++ & + or - & $x$ & drop $x$ & - \\
\hline Na-glycocholate, $2 \%$ & + & + or - & $x$ & drop $x$ & - \\
\hline Ethylalcohol, $50 \%$ & - & & 0 & & \\
\hline Methylalcohol, $50 \%$ & - & - & 0 & $x$ & - \\
\hline Phenol, 1/10 M & + & + or - & $x$ & $x$ & - \\
\hline
\end{tabular}


Table 2, a

(Materials immersed for 4 hours).

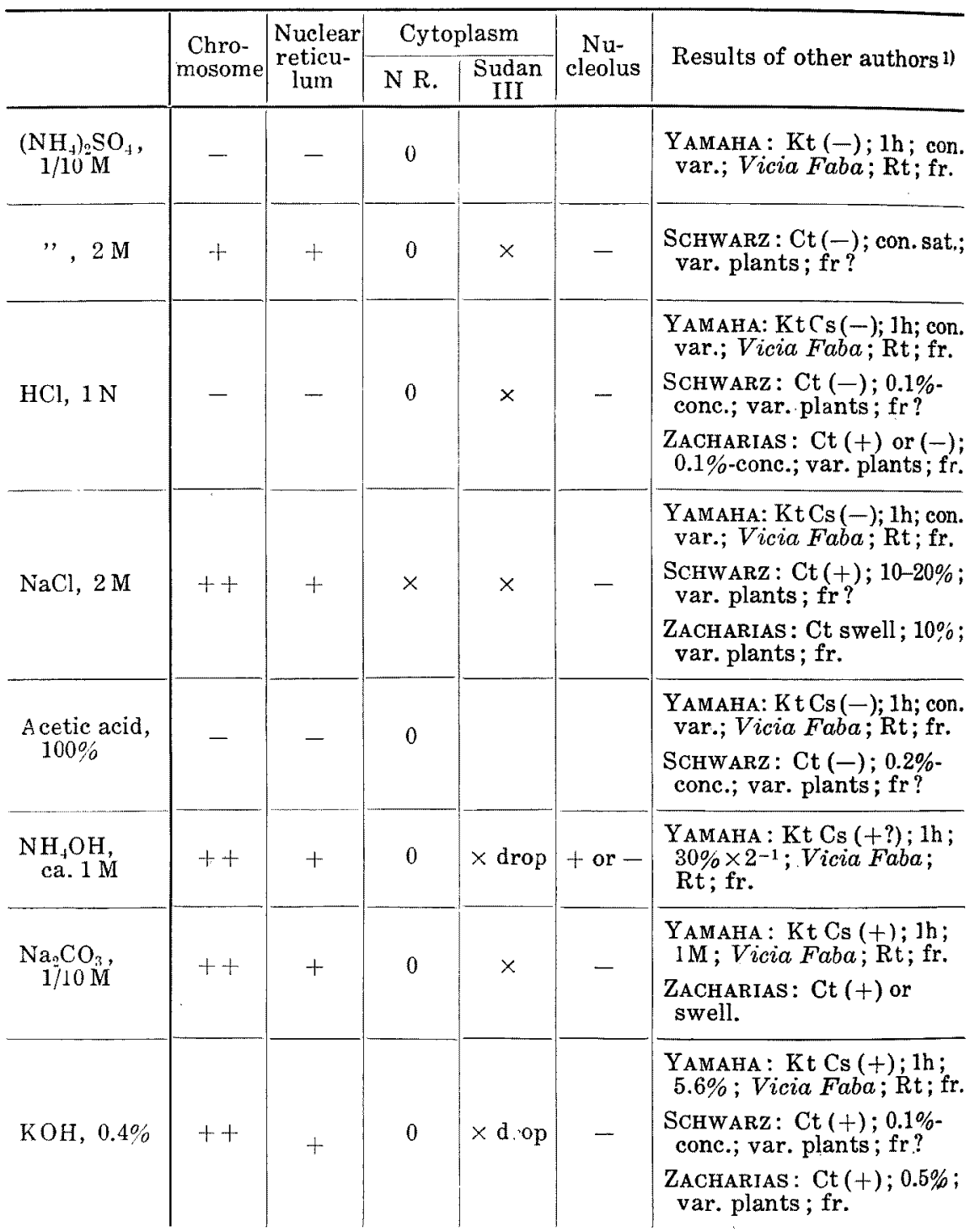

1) SChWARZ (1\&92), p. 18 ?

$\{$ Zacharias after Pratje $(1900)$.

YamaHa (1927). 
Table 2, b

(Materials immered for 24 hours).

\begin{tabular}{|c|c|c|c|c|c|}
\hline & \multirow{2}{*}{$\begin{array}{l}\text { Chromo- } \\
\text { some }\end{array}$} & \multirow{2}{*}{$\begin{array}{l}\text { Nuclear } \\
\text { reticulum }\end{array}$} & \multicolumn{2}{|c|}{ Cytoplasm } & \multirow{2}{*}{ Nucleolus } \\
\hline & & & N.R. & Sudan III & \\
\hline$\left(\mathrm{NH}_{4}\right)_{2} \mathrm{SO}_{4}, 1 / 10 \mathrm{M}$ & - & & 0 & & \\
\hline$" \quad, 2 \mathrm{M}$ & + & + & $\times$ drop & $0 ?$ & - \\
\hline $\mathrm{HCl}, 1 \mathrm{~N}$ & - & - & 0 & $x$ & - \\
\hline $\mathrm{NaCl}, 2 \mathrm{M}$ & ++ or + & + & $\times ?$ & $x$ drop & - \\
\hline Acetic acid, $100 \%$ & $-*$ & $-*$ & 0 & 0 & - \\
\hline $\mathrm{NH}_{4} \mathrm{OH}$, ca. $1 \mathrm{M}$ & ++ & + & 0 & $x$ drop & + \\
\hline $\mathrm{Na}_{2} \mathrm{CO}_{3}, 1 / 10 \mathrm{M}$ & ++ or + & + & $0 ?$ & $\times$ drop & + or - \\
\hline $\mathrm{KOH}, 0.4 \%$ & ++ or + & + or - & $0 ?$ & $x$ drop & + \\
\hline
\end{tabular}

From Table 2, it is seen that the nuclear reticulum and the chromosomes (both matrix and spiral portions) are dissolved in alkaline solutions such as $\mathrm{Na}_{2} \mathrm{CO}_{3}, \mathrm{KOH}$ and $\mathrm{NH}_{4} \mathrm{OH}$, and also in some other reagents such as $\left(\mathrm{NH}_{4}\right)_{2} \mathrm{SO}_{4}$ and $\mathrm{NaCl}$, all of which are reported to be solvents of nucleoproteins in certain concentrations (RoLLETT, 1911, p. 986). In these cases, the nucleal-reaction shows that nucleic acid is dissolved within the boundary of the nucleus, and in most cases no noticeable trace of it is found in the cytoplasm coming out beyond the compass of the nucleus. This fact makes a sharp contrast to the result we obtained when the material was immersed in lipoid solvents.

The reticulum and chromosomes are also dissolved in some other reagents; the results obtained with fresh material are shown in Table 3.

In these cases given in Table 3 the nucleal-reaction shows that some sulphates, ammonium sulphocyanide, and potassium phosphate dissolve the chromosomes without causing diffusion of nucleic acid out of them into the cytoplasm, while the solution by $\mathrm{ZnSO}_{4}$ or $\mathrm{FeCl}_{5}$ is accompanied by this diffusion of nucleic acid into the cytoplasm. 
Table 3, a

(Materials immersed for 4 hours)

\begin{tabular}{|c|c|c|c|c|c|c|}
\hline & \multirow{2}{*}{$\begin{array}{l}\text { Chro- } \\
\text { mosome }\end{array}$} & \multirow{2}{*}{$\left|\begin{array}{c}\text { Nuclear } \\
\text { reticu- } \\
\text { lum }\end{array}\right|$} & \multicolumn{2}{|c|}{ Cytoplasm } & \multirow{2}{*}{$\begin{array}{l}\mathrm{Nu}- \\
\text { cleolus }\end{array}$} & \multirow{2}{*}{ Results of other authors 1} \\
\hline & & & N.R. & $\begin{array}{l}\text { Sudan } \\
\text { III }\end{array}$ & & \\
\hline $\mathrm{ZnSO}_{4}, 1 \mathrm{M}$ & + & + or - & 0 or $x$ & $x$ & - & $\begin{array}{l}\text { YAMAHA: KtCs }(-) ; 1 \mathrm{~h} ; \text { con. } \\
\text { var.; Vicia Faba; Rt; fr. }\end{array}$ \\
\hline $\mathrm{Na}_{2} \mathrm{SO}_{4}, 1 / 2 \mathrm{M}$ & + & + & 0 & $x$ drop & - & $\begin{array}{l}\text { YAMAHA : Kt }(+?) ; 1 \mathrm{~h} ; \mathrm{Mx} \\
2^{-1} ; \text { Vicia Faba; Rt; fr. } \\
\text { ZACHARIAS: Ct swell; } 10 \% \text {; } \\
\text { var: plants; fr. }\end{array}$ \\
\hline $\mathrm{MgSO}_{4}, 1 / 5 \mathrm{M}$ & $\begin{array}{c}++ \text { or } \\
-\end{array}$ & + or - & 0 & $x$ & - & $\begin{array}{l}\text { YAMAHA: Kt }(-) ; 1 \mathrm{~h} \text {; con. } \\
\text { var.; Vicia Faba; Rt; fr. } \\
\text { ScHWARTz: Ct }(+) \text {; con. } \\
\text { sat.; var. plants; fr? }\end{array}$ \\
\hline $\mathrm{CuSO}_{4}, 1 \mathrm{M}$ & $\left|\begin{array}{c}++ \text { or } \\
+\end{array}\right|$ & + or - & 0 & $x$ & - & $\begin{array}{l}\text { YaMAHA : Kt }(+) ; 1 \mathrm{~h} ; 1 \mathrm{M} \text {; } \\
\text { Vicia Faba; Rt; fr. } \\
\text { ScHWARTz: Ct }(+?) \text {; var. } \\
\text { plants; fr? }\end{array}$ \\
\hline $\mathrm{NH}_{4} \mathrm{CNS}, 1 \mathrm{M}$ & $+t$ & + & $\begin{array}{l}0 \text { or } x \\
\text { drop }\end{array}$ & $\times$ drop & - & $\begin{array}{l}\text { YAMAHA : Kt Cs }(+) ; 1 \mathrm{~h} ; \\
1 \mathrm{M} ; \text { Vicia Faba; Rt; fr. }\end{array}$ \\
\hline $\mathrm{NaHCO}_{3}, 1 \mathrm{M}$ & + or - & + or - & 0 & $x$ & - & $\begin{array}{l}\text { YАMAHA : Kt }(+?) ; \mathrm{h} ; \mathrm{Mx} \\
2^{-1} ; \text { Vicia Faba; Rt; fr. }\end{array}$ \\
\hline $\mathrm{FeCl}_{3}, 1 \mathrm{M}$ & + & + or - & $x$ & $x$ & - & $\begin{array}{l}\text { YАMAHA : Kt Cs }(+) ; 1 \mathrm{~h} ; \\
1 \mathrm{M} ; \text { Vicia Faba; Rt;fr. }\end{array}$ \\
\hline $\begin{array}{l}\mathbf{K}_{4}\left(\mathrm{Fe}(\mathrm{CN})_{i}\right) \\
\quad 1 / 50 \mathrm{M}\end{array}$ & + or - & - & 0 & $x$ & - & $\begin{array}{l}\text { YАMAHA : Kt }(+) ; 1 \mathrm{~h} ; \mathrm{M} \times \\
2^{-2} ; \text { Vicia Faba; Rt;fr. }\end{array}$ \\
\hline$\underset{1 \mathrm{M}}{\mathrm{K}_{3}\left(\mathrm{Fe}(\mathrm{CN})_{6}\right)}$ & + & + & 0 & $x$ & - & $\begin{array}{l}\text { YAMAHA: Cs }(+) ; 1 \mathrm{~h} ; 1 \mathrm{M} ; \\
\text { Vicia Faba; Rt; fr. }\end{array}$ \\
\hline $\mathrm{KH}_{2} \mathrm{PO}_{4}, 1 \mathrm{M}$ & + or - & $-^{*}$ & 0 & & & $\begin{array}{l}\text { ScHWARTz: } \mathrm{Ct}(+) ; 1-5 \% \\
\text { var. plants; fr? }\end{array}$ \\
\hline $\mathrm{AgNO}_{3}, 1 / 5 \mathrm{M}$ & -*? & $-* ?$ & 0 & $x$ & - & $\begin{array}{l}\text { YАмАнА: Kt Cs }(-) ; 1 \mathrm{~h} ; \mathrm{M} \\
\quad \times 2^{-1} ; \text { Vicia Faba; Rt; fr. }\end{array}$ \\
\hline $\begin{array}{l}\text { Formic acid, } \\
50 \%\end{array}$ & $\stackrel{-}{-}$ & & 0 & & & $\begin{array}{l}\text { YАMAHA: Kt Cs }(-) ; 1 \mathrm{~h} ; \text { con. } \\
\text { var.; Vicia Faba; Rt; fr. }\end{array}$ \\
\hline $\begin{array}{l}\text { Boric acid, } \\
1 / 5 \mathrm{M}\end{array}$ & - & & 0 & & & $\begin{array}{l}\text { YАMAHA: KtCs }(-) ; 1 \mathrm{~b} ; \text { con. } \\
\text { var.; Vicia Faba; Rt; fr. }\end{array}$ \\
\hline $\begin{array}{l}\text { Na-citrate, } \\
1 / 10 \mathrm{M}\end{array}$ & - & & 0 & & & \\
\hline
\end{tabular}

1) See the note at the foot of Table 2,a. 
Table 3, a (Continued)

\begin{tabular}{|c|c|c|c|c|c|c|}
\hline & \multirow{2}{*}{$\begin{array}{c}\text { Chro- } \\
\text { mosome }\end{array}$} & \multirow{2}{*}{$\begin{array}{l}\text { Nuclear } \\
\text { reticu- } \\
\text { lum }\end{array}$} & \multicolumn{2}{|c|}{ Cytoplasm } & \multirow{2}{*}{$\begin{array}{l}\text { Nu- } \\
\text { cleolus }\end{array}$} & \multirow[b]{2}{*}{ Results of other authors } \\
\hline & & & N.R. & $\begin{array}{l}\text { Sudan } \\
\text { III }\end{array}$ & & \\
\hline $\begin{array}{l}\text { Na-acetate, } \\
1 \mathrm{M}\end{array}$ & + or - & + or - & 0 & $x$ & - & $\begin{array}{l}\text { YaMAHA: KtCs(--); } 1 \text {; ; con. } \\
\text { var.; Vicia Faba; Rt; fr. }\end{array}$ \\
\hline $\mathrm{CdCl}_{2}, 2 \mathrm{M}$ & - & & 0 & & & $\begin{array}{l}\text { YAMAHA: KtCs }(+?) ; 1 \mathrm{~h} \\
2 \mathrm{M} ; \text { Vicia Faba; Rt;fr. }\end{array}$ \\
\hline $\begin{array}{c}\text { Grape sugar, } \\
1 / 10 \mathrm{M}\end{array}$ & - & & 0 & & & \\
\hline
\end{tabular}

Table 3, b

(Materials immersed for 24 bours).

\begin{tabular}{|c|c|c|c|c|c|}
\hline & \multirow{2}{*}{$\begin{array}{l}\text { Chromo- } \\
\text { some }\end{array}$} & \multirow{2}{*}{$\begin{array}{l}\text { Nuclear } \\
\text { reticulum }\end{array}$} & \multicolumn{2}{|c|}{ Cytoplasm } & \multirow{2}{*}{ Nucleolus } \\
\hline & & & N.R. & Sudan III & \\
\hline $\mathrm{ZnSO}_{4}, 1 \mathrm{M}$ & + & + & $\times$ drop? & $\times$ drop & - \\
\hline $\mathrm{Na}_{2} \mathrm{SO}_{4}, 1 / 2 \mathrm{M}$ & ++ or + & + & $\times ?$ & $x$ drop & - \\
\hline $\mathrm{MgSO}_{4} 1 / 5 \mathrm{M}$ & $t+$ or $t$ & + or - & $\times ?$ & $x$ drop & - \\
\hline $\mathrm{CuSO}_{4}, 1 \mathrm{M}$ & ++ or + & + or & 0 & $x$ & - \\
\hline $\mathrm{NH}_{4} \mathrm{CNS}, 1 \mathrm{M}$ & ++ & + & 0 & $\times$ drop & - \\
\hline $\mathrm{NaHCO}_{3}, 1 \mathrm{M}$ & + & + & 0 & $x$ & - \\
\hline $\mathrm{FeCl}_{3}, 1 \mathrm{M}$ & $+t$ & - & $x$ & $x$ & + or - \\
\hline $\mathrm{K}_{1}\left(\mathrm{Fe}(\mathrm{CN})_{6}\right), 1 / 50 \mathrm{M}$ & + & - & 0 & $x$ & - \\
\hline $\mathrm{K}_{3}\left(\mathrm{Fe}(\mathrm{CN})_{6}\right), 1 \mathrm{M}$ & + & + & 0 & $\times$ & - \\
\hline $\mathrm{KH}_{2} \mathrm{PO}_{4}, 1 \mathrm{M}$ & ++ & + & 0 & & \\
\hline $\mathrm{AgNO}_{3}, 1 / 5 \mathrm{M}$ & -*? & -*? & 0 & $x$ & - \\
\hline Formic acid, $50 \%$ & - & & 0 & & \\
\hline Boric acid, 1/5M & - & & 0 & & \\
\hline Na-citrate, $1 / 10 \mathrm{M}$ & - & & 0 & & \\
\hline Na-acetate, $1 \mathrm{M}$ & ++ or - & - & 0 & $x$ & - \\
\hline $\mathrm{CdCl}_{2}, 2 \mathrm{M}$ & - & & 0 & & \\
\hline Grape sugar, 1/10M & - & & 0 & & \\
\hline
\end{tabular}


Some important details of the results obtained in these tests (Tables 1, 2 and 3) may be given here in a summarised form.

1) In material first treated with chloroform or amylalcohol and then fixed with Ciaccio's method, there are often found some amorphous bodies in the nucleus which are stained reddish orange with Sudan III (Fig. 7).

2) In material immersed in chloroform, benzene, $\mathrm{NaCl}, \mathrm{Na}_{2} \mathrm{CO}_{3}$ or some sulphates, a number of intranuclear drops which are positive to the nucleal-reaction are found.

3) In material immersed in amylalcohol, benzene, aniline, chloroform, $\left(\mathrm{NH}_{4}\right)_{2} \mathrm{SO}_{4}$, etc., in which the matrix of the chromosomes swells and thus the spiral portion is clearly distinguishable from it, it is observed that the former is positive to the nucleal-reaction, while the latter is negative.

4) The matrix portion of chromosomes is dissolved in the lipoid solvents far more rapidly than the spiral portion, so that the chromosome may often be represented by the latter only (Fig. 8). The same fact has been observed by one of us (M. S.) in his study of the influence of Na-glycocholate on the mitotic figures in pollen mother cells in Tradescantia reflexa.

5) When the chromosome matrix is swollen by the action of the reagents named in (3), it is not stained by CIACCIo's method of lipoid staining.

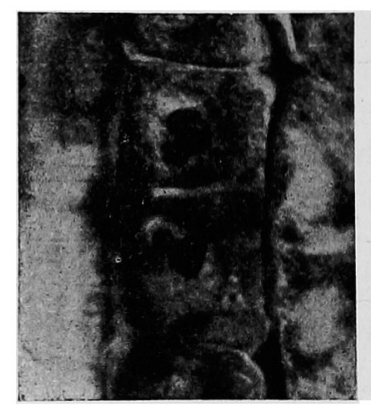

7

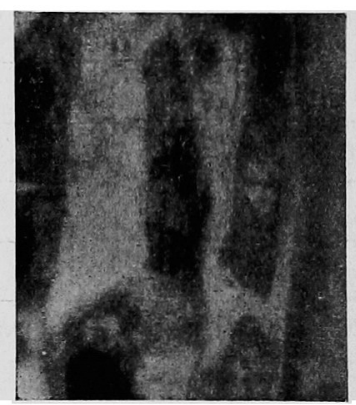

8

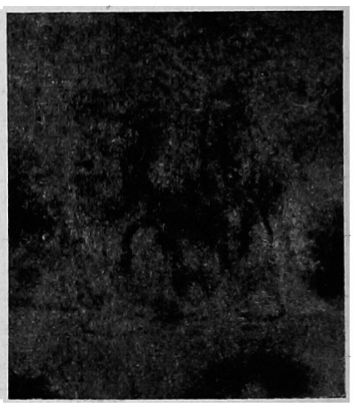

9

Fig. 7. Part of periblem in root tip of Vicia Faba immersed in chloroform water for 24 hours, and counter-stained with Ciaccio's method and HeidenHaIN's haematoxlin. Fig. 8. Part of plerome of the same immersed in amylalcohol water for 24 hours and stained with Heidenhain's haematoxylin. Fig. 9. Part of periblem of the same treated with boiling water for about 20 seconds showing nucleal-reaction of chromosome spiral. In the majority of the chromosomes the spirals are found-imbedded within the swollen matrix, and in some they have disappeared. 
An important result which must be added to those mentioned above is that obtained from the boiling experiment. In preparations in which the chromosome spiral is rendered clearly distinguishable from the matrix by treating material with boiling water, the positive nuclealreaction is observed only in the spiral portion and there is no trace of the reaction in the matrix, while it is observed in the peripheral portion of the matrix as well as in the surrounding cytoplasm when the spiral has been caused to disappear by longer treatment of the material with boiling water (Fig. 9). It may also be added here that the result of NĚMEC's (1910) experiment with boiling water was corroborated in these tests: The resting nucleus is far more strongly resistant to the action of boiling water than the chromosomes are.

Summing up the results we may conclude :-

1) The results of tests given in Tables 1 and 2 and the detailed observations (1) and (2) just mentioned above conform to those stated in chapters $\mathrm{I}$ and II.

2) In No. (3) of the detailed observations, it is stated that the spiral portion of the chromosome, which remains intact, is stained by the nucleal-staining method. This fact shows that this portion contains nucleic acid or nucleoprotein as a chemical constituent.

3) From details (3) and (4), it may be concluded that the matrix portion contains lipoids but no nucleic acid, although the fact mentioned in detail (5) forms no positive evidence for this conclusion.

4) In connection with these conclusions (2) and (3), it is worth while emphasizing that, as mentioned above, the mode of the solution by nucleoprotein solvents is quite different from that caused by lipoid solvents. That is to say, through the action of the latter solvents nucleic acid comes out of the nucleus or the territory of the chromosomes and diffuses into the surrounding cytoplasm, while it is confined within the boundary of nucleus when solvents of nucleoproteins are used. We may then say that the solution in more complete with lipoid solvents than with nucleoprotein solvents, and are led to the conclusion that nucleoproteins are imbedded in the lipoid substances.

\section{2) Test with the Staining Method}

As is stated by Pratje (1920), Wilson (1925), Wermel (1927) and other authors, the staining method is by no means trustworthy in itself for histochemical investigation, but it may have throw some light upon the problem in question if it is used as a supplementary test. From 
this point of view we employed PAPPENHEIM-UnNA's method in the present investigation. (UNNA, 1928, p. 13).

i) Pollen mother cello in Tradescantia reflexa fixed according to CiACCIo's method.

Chromosomes in metaphase and anaphase in the heterotype division retain only the red colour of pyronin, while the cytoplasm takes both pyronin and methylgreen, appearing purple. The nuclei in the periplasmodium and those in the anther tissue are stained purple or blue.

ii) Pollen mother cells in Lilium tigrinum fixed with absolute alcohol.

The spiremes in the prophase are stained blue, while the cytoplasm and nucleolus are red.

iii) Root tip cells in Vicia Faba fixed according to CIACCIO's method.

In the resting nucleus the nuclear reticulum is blue, making a sharp contrast to the nucleolus which stains red. In the late prophase, metaphase and anaphase, the chromosomes are red, while in the telophase they are purple. The daughter nuclei in the late telophase stain blue like the resting nucleus, and the spindle fibers and the cytoplasm red like the chromosomes in metaphase and anaphase.

The results mentioned above show that the resting nuclei take methylgreen, while the chromosomes in the late prophase, metaphase, and anaphase are stained with pyronin. LiLIENFELD (1893) ${ }^{1}$ states on the other hand that the chromosomes too take methylgreen. According to UNNA (1928), methylgreen stains nucleoprotein, and pyronin other acid proteins. Thus the conclusion to be drawn from these results should be that in the nuclear reticulum the main substance is nucleoprotein, while in the chromosomes there is some acid protein in addition to it.

\section{Conclusion and Discussion Resting Nucleus}

Reticulum. To speak in morphological terms, the nucleus is composed of the reticulum and the karyolymph, in which a nucleolus or nucleoli, whose nature is still obscure, are suspended. The reticulum is not a homogeneous structure, but heterogeneous, consisting of the continuous achromatic basis and the chromatic substance which forms a more or less discontinuous structure suspended in it-the chromatin. As to the chemical nature of chromatin, we have two different

1) Cited from ManN (1902). 
opinions. Most biochemists entertain the opinion, based on macrochemical analysis, that it is a nucleoprotein such as nucleate-histone or nucleate-protamine (MaTHEWs, 1930), and many authors who adhere to this opinion have endevoured to confirm this view histochemically by various methods.

The second opinion is that represented by HANSTEEN-CrANNER (1919), GraFe (1925), Grafe and MAGistris (1926), and GutSTEIN (1927), who believe that lipoids are the main constituent of the nucleus. GRAFE (1925), GRAFE and MAGISTRIS (1926), and GUTSTEIN (1927) have experimentally demonstrated an affinity between lipoids and the so-called nuclear dyes, and interpret the strong affinity known to exist between basic dyes and the cell nucleus, as due to the affinity of the dyes for phosphatides contained in the nucleus.

The results we obtained in the present investigation are in harmony with both these opinions. In the first place, that nucleic acid or nucleoprotein is present in the reticulum, in which chromatin is the principal constituent, is shown by the fact that in certain plants the nuclear reticulum is positive to the nucleal-reaction of FEULGEN. A weak reaction or negative result obtained in some other plants may be explained as due to the fact that in these plants the nucleic acid or the nucleoprotein, if there is any, is of another kind, that presents no typical nucleal-reaction. In the second place we have evidence to show that lipoid substances must exist in the reticulum. It is, though the colour is not always typical, coloured with CiACcro's method of lipoid staining with which the detection of certain lipoids is possible. It must, of course, here be remembered that this method does not rest so much on a chemical basis, and also that the stainability of tissues may change to a considerable extent according to the preliminary treatment of the tissues (ToLsTOOUHOv, 1928 and ZEIGER, 1930). Thus we may not be able to draw a definite conclusion from the results obtained with this method alone, but they are in conformity with the results obtained by the well-known lipoid staining with Nile blue sulphate, Scharlach red and chlorophyll, so far as the tests we made are concerned. The question arises, then, whether these substances, thymusnucleic acid and lipoids, exist in the nucleus in the free form or combined. In our tests it is shown by MILLoN's reaction that proteins are also present in the reticulum, and hence it seems highly probable that they form nucleoproteins with nucleic acid. According to WERMEL (1927), there is very little free nucleic acid in the living nucleus. The result ${ }^{1)}$ of precipitation experiments

1) Unpublished. 
made on nuclei by one of us (N.S.) also points to this conclusion. In these experiments it has been shown that the optimum $\mathrm{H}$-ion concentration for the precipitation of the substances in the reticulum and the chromosomes is nearly the same as that of some nucleoproteins.

From the positive MiLLoN's reaction of the reticulum it seems also probable that lipoids may exist in the form of lipoprotein, partly at least, as assumed by GuTSTEIN (1927). Our tentative conclusion is, therefore, that the reticulum contains as its chemical constituents thymusnucleic acid which is present as nucleoprotein, and a certain amount of lipoids which may also partly combine with other substances, probably with protein into lipoproteins. With regard to the localisation of these substances in the reticulum we are at present not in a position to speak with any certainty, but, so far as the nucleal-reaction is concerned, as will be discussed later, it seems likely from the results of tests made on chromosomes that the localisation of nucleoprotein is mainly connected with the distribution of chromatin in the morphologically welldefined sense.

In harmony with this conclusion, we have the results of tests given in Tables 1 and 2 that fresh nuclei in root tip cells of Vicia Faba are generally dissolved by lipoid solvents such as ethyl-ether, chloroform, benzene, amylalcohol, aniline, and xylene as well as by other reagents such as $\mathrm{NaCl},\left(\mathrm{NH}_{4}\right)_{2} \mathrm{SO}_{4}, \mathrm{NH}_{4} \mathrm{OH}, \mathrm{NaCO}_{3}, \mathrm{Na}$-acetate etc. which are known to dissolve nucleoproteins or nucleic acid. OES (1908 and 1910) has made similar tests with fresh material by immersing it in water solutions of toluene, chloroform and phenol with or without a certain amount of neutral salts such as $\mathrm{NaCl}, \mathrm{KNO}_{3}$, and $\mathrm{NaNO}_{3}$, and has obtained the result that chromatin and chromosomes are dissolved with these solutions. He has regarded this result as due not to the direct action of the solutions, but to an enzyme action in the cell, without giving any explanation as to the rôle played by these solutions in dissolving the material. The results of parallel experiments which he carried out with fresh plant tissue extract on the one hand and with that heated at $75-80^{\circ} \mathrm{C}$ on the other appear to substantiate his conclusion, and the result we obtained that the solution of chromatin is hindered to a greater or less extent by the preliminary treatment of the material with acetic acid might also be looked upon as confirming this idea of OEs. As suggested by Ň̈MEc (1910), however, another interpretation than that the effect is due to destruction by the enzyme is possible in the case of these results obtained by OEs as well as by us. 
In the experiments which OES carried out by adding nitrates and sulphates respectively to toluene, there are some points which are not clearly comprehensible; in the former the point is what rôle is played here by the nitrate which alone has nothing to do with the solution of chromatin or chromosomes, and in the latter it is for what reason the result OES obtained is not in harmony with ours as well as YAMAHA's (1927), in both of which it is shown that sulphates dissolve koth chromatin and chromosomes. If we put aside the results OES obtained in these two experiments for the present, the results from the other experiments he carried out, in which toluene, chloroform and phenol were used together with $\mathrm{NaCl}$, can easily be explained as due to the direct action of these reagents upon chromatin and chromosomes provided that they contain some notable amount of lipoids or lipoproteins and nucleoproteins or nucleic acids, because toluene, chloroform and phenol are all lipoid solvents, and $\mathrm{NaCl}$ is known to be a reagent which dissolves in certain concentrations those nucleoproteins isolated from blood serum and corpuscles, and nucleohistone obtained from thymus. NĔMEC (1910) express the view that the solution of chromatin may not necessarily involve the action of an enzyme, but may also take place through the simple action of water or a non-enzymatic substance in the extract from plant tissues (p. 319).

We do not intend here to discuss the problem further, because the question at issue is merely whether or not the reticulum and chromosomes are dissolved by reagents known to be lipoid solvents and nucleoprotein or nucleic acid solvents in any way whatever, whether it is due to the direct action of the reagents or not. If they are not dissolved, the conclusion we have drawn from the results we obtained in the histochemical tests may be wrong, but if they are dissolved, the dissolving tests will supply no evidence on which it can be positively denied, even though they may not serve to support it. The results given in Tables 1 and 2 show that the latter assumption is actually the case.

In Spirogyra sp. the nucleus gives no thy musnucleic acid reaction, while it is distinctly positive to MILLON's reagent. This characteristic feature of Spirogyra nucleus rouses a certain interest when we consider the view of MoLL (1893) ${ }^{11}$ and some others who regard the nucleus of this alga as being free from chromatin.

Ka r y ol y m ph. Voss $(1925 / 26)^{2)}$ reported that the karyolymph is positive to the nucleal-reaction in the resting nucleus, but that when

1) Cited from ZimmermanN (1895) p. 471.

2) Cited from KIESEL (1930). 
the nucleus begins to prepare for division, the positive reaction is recognizable only in the chromatic threads. WERMEL (1927) obtained a result, contrary to that of Voss, namely that thymusnucleic acid is absent in the karyolymph. This result is quite in accord with that which we obtained. In the tests we made, the karyolymph showed no positive result in any of the tests for thymusnucleic acid, lipoids, and proteins. The precipitation method, on the other hand, gives results ${ }^{1)}$ which support the idea that lipoids are contained in the karyolymph too. In this test we found that water solutions of $\mathrm{CdCl}_{2}$, grape sugar, and $\left(\mathrm{NH}_{4}\right)_{2} \mathrm{SO}_{4}$ generally cause the karyolymph to present an opalescent appearance when seen with dark field illumination, a phenomenon known in phosphatides, while the solutions of $\mathrm{NaCl}$ and $\mathrm{Na}_{2} \mathrm{SO}_{4}$ cause no turbid appearance at all. We are reminded, then, of GRAFE and MAGISTRIS' statements :- “ Auch hier könnte der Kernsaft aus löslichen Phosphatiden bestehen, die aus sich heraus bis zu einem bestimmten Gleichgewicht chromatische Substanz (unlösliche Phosphatide) bilden" (1926). Here, of course, we take the "chromatische Substanz" as meaning the so-called achromatic basis of the reticulum or the matrix of chromosomes. The positive nucleal-reaction of chromosome spirals compels us to the idea that the chromatic substance consists mainly of nucleic acid or nucleoprotein.

$\mathrm{Nucleol}$ us. As WILSON states (1925), the nucleolus is a structure still imperfectly understood, and therefore, a general discussion of its chemical nature is at present hardly possible, and accordingly we have to consider it in a rather vague sense. One of the prevailing opinions held among cytologists, that the nucleolus is the reservoir of chromatin (see TISCHLER, 1921/22, p. 52-53), is not based on satisfactory chemical grounds, but is a conclusion drawn from certain morphological evidence found in the nucleolus and chromosomes, and from stainability facts such as, for instance, that the decreases in stainability of the nucleolus is proportional to the increasing chromaticity of the developing chromosomes. These are results of observations from materials which have been fixed with mixtures containing heavy metal compounds; so that, as is well known, the properties of tissues vis à vis dyes may have been altered by the action of the fixing mixtures.

Our knowledge of the nucleoli derived from histochemical research is rather meagre. According to ZACHARIAS (1885) the nucleolus contains no nuclein, but proteins and plastin. UNNA and FEIN (1921) also report

1) Unpublished. 
that no nucleic acid is found in plant nucleoli, while according to UNNA (1928) animal nucleoli contain a mixture of globuline and nucleic acid. VOSS $(1925 / 26)^{1)}$ reports, on the other hand, that the nucleoli in somatic cells are positive to FEULGEN's nucleal-reaction while those in germ cells are negative. With the root tip cells of Vicia Faba, however, HEITZ (1931) obtained a negative result with FEuLgen's method. This diversity in the results seems to show that the nucleolus is not universally the same in its chemical constitution, though some other factors concerned with the testing method may also be a cause of the diversity in part. According to the results we obtained with root tip cells of Vicia Faba, lipoid staining is definitely positive, while MILLON's reaction is comparatively indefinite, and according to those with somatic cells in Zea Mais, Marsilia quadrifolia, and Vicia Faba, and those from microspore mother cells in Lilium tigrinum, Allium Cepa, Psilotum sp. and Salvinia natans, the nucleal-reaction is negative. The nucleoli in the spermatocytes of an insect (Oxya sp.) with which we made tests on one occasion have also given similar results in all the tests. With the dissolving method, the nucleolus is very resistant to most of the reagents which we employed. Thus it may be concluded that the nucleolus contains lipoids as reported by FeLs $(1926)^{2)}$ but no thymusnucleic acid, so far as the plants we investigated are concerned.

\section{Dividing Nucleus}

Chromosomes. The results we obtained from the tests with chromosomes are: 1) the chromosome gives positive lipoid and protein reactions though they may not always be typical, 2) the spiral portion of the chromosome shows the positive nucleal-reaction, while its matrix or substratum remains uncoloured, 3) the matrix is far more easily dissolved by lipoid solvents than the spiral portion of the chromosome. ZACHARIAS (1881), MATHEWS (1930), LEPESCHKIN (1924) and others consider that nucleoproteins or nuclein is the constituent substance of the chromosome, while LILIENFELD ${ }^{3)}$ believes it to be free nucleic acid. Our results are so far in harmony with these opinions that the chromosomes are positive to FEULGEN's nucleal-reaction, but will not be in agreement with them if nucleoproteins are taken to be the sole constituent substance of chromosomes, because we have the facts that they are stained with lipoid staining dyes, and that they are dissolved with lipoid solvents

1) Cited from KIESEL (1930). p. 182.

2) Cited from KIESEL (1930). p. 182.

3) Cited from PRATJE (1920). p. 94. 
far more easily than with nucleoprotein solvents. The results we obtained, therefore, lead to the conclusion that the chromosomes are composed not merely of nucleoproteins, but also of lipoids.

HANSTEEN-CRANNER (1919) express the view that the spiral portion of the chromosomes probably consists of a lipoid substance. The results we obtained, however, do not conform to this view, because this portion shows a clear FEULGEN's nucleal-reaction, and it is less easily dissolved with lipoid solvents than the matrix portion. Our conclusion is therefore that the spiral portion consists mainly of nucleoproteins probably in company with some amount of lipoids, and the matrix with which FEULGEN's reaction is scarcely positive consists chiefly of lipoids which are in the free state or combined with proteins. YAMAHA (1932) reports that SCHUMACHER's method of lipoid staining is positive in the outer layer of chromosomes (Chromosomenhülle).

In connection with this conclusion we have drawn special interest attaches to the view of GRAFE (1922) that the material of which nucleic acid is make up may be derived from phosphatides in protoplasm ( $p$. 146), and to the opinion of ALEXANDER and BRIDGES (1928) who assume that oxychromatin or the main substance of the chromosome matrix is derived from basichromatin or the main substance of the chromosome spiral through the action of chromatin-hydrolysing enzymes (p. 41).

Now we come to the next question, whether there is a certain difference between the constituent substances of the reticulum and chromosomes. LILIENFELD (1893) ${ }^{1)}$ is of the opinion that nucleic acid is the main substance of the chromosome in metaphase, little or only a small amount of protein being present in it, while both are constituents of the nucleus in the resting stage. This opinion is based on the results of his test, that the chromosome stains green with EHRLICH's mixture of methylgreen, acid fuchsin and orange $G$, while the resting nucleus is bluish green with this mixture. While LILIENFELD's opinion was not accepted by HEINE (1895/96), it has been assumed by OES (1908), NĚMEC (1910) and some others that an increase in the amount of nucleic acid or chromatic substance takes place during the process of mitosis. In connection with this problem KIESEL (1930) considers the possible activity of FEuLgen's nucleogelase.

The results of our investigation are not quite definite enough to enable us to discuss this problem, but the following three points may be mentioned here. 1) There is a difference between the nucleus and

1) Cited from Pratue (1920). 
the chromosomes in the intensity of the reaction colour produced with Feulgen's method; it is lighter in the former than in the latter. According to WIDSTRöm (1928) the intensity of the reaction colour is not necessarily proportional to the amount of nucleic acid, if protein is present mixed together with it. If, therefore, a variation in the intensity is observed, it must show that it is due to variation in either the amount of nucleic acid or the presence or absence of protein. 2) Chromosomes in pollen mother cells of Tradescantia reflexa give a positive result with CIACCIo's method of lipoid staining, taking much Sudan III and a little of HEIDENHAIN's haematoxylin, while the reticulum in the interkinetic nucleus (P.M.C.) as well as the resting nucleus of the anther tissue retains the colour of HEIDENHAIN's haematoxylin more than that of Sudan III. 3) In root tip celis of Vicia Faba, stained with PAPPENHEIMUNNA's method, the nuclear reticulum is blue, while the chromosomes in the late prophase and the metaphase are red. From these differences in the staining or colour reaction found between the resting and dividing nuclei, we may draw the conclusion that there take place in the nucleus certain changes, chemical or physicochemical, during mitosis.

Phragmoplast and Spindle Fibers. As to the chemistry of the phragmoplast and spindle fibers our knowledge is meagre. In the present investigation, it is shown that the phragmoplast generally gives a distinct positive reaction to MILLON's reagent and a positive result with CIAccio's lipoid stain method, while it is negative to the nucleal-reaction. Thus, we may conclude that the chemical constituents of the phragmoplast are mainly lipoids and proteins in the free form or combined into lipoproteins. The spindle fibers also give positive results when stained with lipoid staining methods, though the colour retained is not always definite. They are positive to MILLoN's reaction too, but negative to the nucleal-reaction as in the case of the phragmoplast.

\section{Summary}

Histochemical tests were made with the resting as well as dividing nuclei in plants with FEULGEN's nucleal-reaction method for the test of thymusnucleic acid, MILLON's, the xanthoproteic and the biuret reaction method for proteins, and CHRISTELLER's, CIACCIO's and other methods of testing for lipoids. The solution analysis method and staining according to PAPPENHEIM-UNNA's method were also used as supplementary means of testing the results obtained with the methods named above. The results we obtained with these methods are as follows : 
1) The nuclear reticulum and chromosomes show reactions of thymusnucleic acid, lipoids and proteins.

2) In the chromosomes the thymusnucleic acid reaction is found exclusively in the spiral portion.

3) The chromosomes are far more easily dissolved by lipoid solvents and nucleoprotein solvents than the resting nucleus is (Tables 1 and 2).

4) Of the two morphological components of chromosomes, the spiral portion and matrix, the former is more resistant to the action of lipoid solvents than the latter.

5) There is some evidence which suggests that certain material changes may take place in the nuclear components during mitosis.

6) The nucleus of Spirogyra sp. shows no thymusnucleic acid reaction but a protein reaction, forming a striking contrast to the other plants investigated.

7) The karyolymph show no positive result in any of the tests for thymusnucleic acid, lipoids, and proteins, but the result obtained with the precipitation method suggests that there may be lipoid in the karyolymph.

8) The nucleolus is shown to contain lipoids, but no thymusnucleic acid.

9) The spindle fibers and the phragmoplast are shown to consist mainly of proteins and lipoids in a mixed or a combined form.

In concluding, the authors wish to express their sincere thanks to Prof. Y. KuWADA for his kind guidance throughout the investigation.

\section{Literature Cited}

Alexander, J. and Bridges, C. B. (1928) Some physico-chemical aspects of life, mutation and evolution. Colloid Chemistry. Vol. 2. p. 9. New York.

Arndt, H. J. (1924) Zum histologisch-färberischen Lipoidnachweis mit Chlorophyll. Zeitschr. f. wiss. Mikrosk. Vol. 41.

Bang, I. (1911) Phosphatide. Bioch. Handlex. Vol. 3. p. 224.

Czapek, F. (1919) Zum Nachweis von Lipoiden in Pflanzenzellen. Ber. deut. bot. Gesell. Vol. 37.

Dische, Z. (1931) Nachweis und Bestimmung der Thymonukleinsäure. Handb. d. biol. Arb.-meth. von ABDERHALDEN. 355.

Feulgen, R. (1926) Die Nuklealfärbung. Handb. d. biol. Arb.-meth. von ABDERHALDEN. 213.

Feulgen, R. and Rossenbeck, H. (1924) Mikroskopisch-chemischer Nachweis einer Nucleinsäure vom Typus der Thymonucleinsäure und die darauf beruhende elektive Färbung von Zellkernen in mikroskopischen Präparaten. Zeitschr. physiol. Chem. Vol. 135.

Fujii, K. (1926) The recent progress in cytology, and methods of its investigation. (Japanese). Rep. Jap. Ass. Adv. Sci. Vol. 2.

Grafe, V. (1922) Chemie der Pflanzenzelle. Berlin.

- (1925) Zur Physiologie und Chemie der Pflanzenphosphatide. Bioch. Zeitschr. Vol. 159 . 
Grafe, V. und Magistris, H. (1926) Über die Phosphatide aus Daucus carota. Planta. Vol. 2.

Gutstein, M. (1926) Zur Theorie der Haematoxylinfärbungen. Ein Beitrag zum färberischen Nachweis der Zelllipoide. VIRchows Arch. Vol. 261.

Hansteen-Cranner, B. (1919) Beiträge zur Biochemie und Physiologie der Zellwand und der plasmatischen Grenzschichten. Ber. deut. bot. Gesell. Vol. 37.

Heine, L. (1895/96) Die Mikrochemie der Mitose. Zeitschr. physiol. Chem. Vol. 21.

Heitz, F. (1931) Die Ursache der gesetzmaßigen Zahl, Lage, Form und Größe pflanzlicher Nukleolen. Planta. Vol. 12.

Kawamura, R. (1911) Die Cholesterinesterverfettung. (Cholesterinsteatose). Jena.

Kiesel, A. (1930) Chemie des Protoplasmas. Berlin.

Mann, G. (1902) Physiological histology. Oxford.

Mathews, A. P. (1930) Physiological chemistry. London.

Meyer, A. (1920) Morphologische und physiologische Analyse der Zellen der Pflanzen und Tiere. Jena.

Němec, B. (1909) Zur Mikrochemie der Chromosomen. Ber. deut. bot. Gesell. Vol. 27.

- (1910) Das Problem der Befruchtungsvorgänge. Berlin.

Oes, A. (1908) Über die Autolyse der Mitosen. Bot. Ztg. Vol, 66.

- (1910) Neue Mitteilung uber enzymatische Chromatolyse. Zeitschr. Bot. Vol. 2.

Pratje, A. (1920) Die Chemie des Zellkernes. Biol. Zentralbl. Vol. 40.

Rollett, A. (1911) Nucleoproteide und Nucleinsäuren. Bioch. Handlex. Vol. 4. p. 986.

Romeis, B. (1928) Taschenbuch der mikroskopischen Technik. 12 ed. München.

Schmidtmann, M. (1928) Mikroskopischer Nachweis der Zellpigmente und Lipoide in tierischen und menschlichen Geweben. Meth. wiss. Biol. von PETERFI. Vol. 1. p. 981 .

Shigenaga M. (1933) On the action of sodium glycocholate on nuclei and chromosomes. Mem. Coll. Sci. Kyoto Imp. Univ. B. Vol. 8. No. 2.

Shwartz, F. (1892) Die morphologische und chemische Zusammensetzung des Protoplasmas. CoHn Beitr. Biol. Pfl. Vol. 5.

Tischler, G. (1921-22) Allgemeine Pflanzenkaryologie. Berlin.

Tolstoouhov, A. V. (1928) The effect of preliminary treatment (Fixing fluid) on staining properties of the tissues. Stain Tech. Vol. 3.

Tröndle, A. (1912) Der Nucleolus von Spirogyra und die Chromosomen höherer Pflanzen. Zeitschr. Bot. Vol. 4.

Unna, P. G. (1928) Histochemie.der Haut. Leipzig und Wien.

Unna, P. G. und Fein, H. (1921) Zur Chromolyse des pflanzlichen Kernkörperchens. Biol. Centralbl. Vol. 41.

Wermel, E. (1927) Untersuchungen über die Kernsubstanzen und die Methoden ihrer Darstellung. I. Mitteil. Zeitschr. Zellforsch. mikrosk. Anat. Vol. 5.

Widström, G. (1928) Über die Verwendbarkeit der SchlFfschen Fuchsinschwefligsäurereaktion zur Quantitativen Bestimmung von Thymonucleinsäure. Bioch. Zeitschr. Vol. 199.

Wilson, E. B. (1925) The cell in developement and heredity. New York.

Yamaha, G. (1927) Experimentelle zytologische Beiträge. I. Mitteil. Orientierungsversuche an den Wurzelspitzen einiger Pflazen. Jour. Fac. Sci. Imp. Univ. Tokyo, Sec. 3 Vol. 2, Part. 1.

- (1932) U̇ber die Färbbarkeit der fixierten Zellstrukturen. Scl. Rep. Tôkyo Bunrika Daigaku. Sec. B. No. 1 Vol. 1.

Zacharias, E. (1881) Utber die chemische Beschaffenheit des Zellkerns. Bot. Ztg. Vol. 39.

- (1885) Über den Nucleolus. Ebenda. Vol. 43.

- (1898) Über Nachweis und Vorkommen von Nuclein. Ber. deut. bot. Gesell. Vol. 16.

Zeiger, K. (1930) Der Einfluß von Fixationsmitteln auf die Färbbarkeit histologischer Element. Versuche mit hochdispersen Farbstoffen. Zeitschr. Zellf. mikrosk. Anat. Vol. 10.

Zimmermann, A. (1895) Über die chemische Zusammensetzung des Zellkernes. I. Zeitschr. wiss. Mikrosk. Vol. 12. 